\title{
Analysis of Aggressive Behavior in High School Students in The City of Pekanbaru
}

\author{
Ainil Fitri ${ }^{1}$, Lora Marlita ${ }^{2}$, Yulia Febrianita ${ }^{3}$, and Putri Wulandini ${ }^{4}$ \\ Lecturer $^{1,2,3,4}$, Diploma 3 Nursing Department ${ }^{1,2,3,4}$ \\ Faculty of Medicine and Health Sciences, Abdurrab University ${ }^{1,2,3,4}$ \\ Jl.Riau Ujung No.73, Pekanbaru, Riau ${ }^{1,2,3,4}$
}

\begin{abstract}
Aggressive behavior is the fourth leading cause of adolescent death in 2016 (Enopadria, 2018). The effects of aggressive behavior on adolescents include physical injuries, psychological injuries and social injuries. This aggressive behavior is not only in the form of physical aggression but can manifest in other forms such as angry behavior, verbal aggression, and show hostility to others (Hardoni, 2019). The purpose of this study is to analyze the aggressive behavior that occurs in adolescents, especially high school students in the Pekanbaru city. The population in this study were high school students in the city of Pekanbaru. The number of samples of this study were 904 adolescents. The sample technique used is accidental sampling. The research instrument uses the Brief Aggression Questionnaire. The results of a study conducted in 2020 on high school students in Pekanbaru city about aggressive behavior were $42.1 \%$ of adolescents showing low aggressive behavior, while another $\mathbf{5 7 . 9 \%}$ showed high aggressive behavior. It is expected that educational sites will activate the PIK-R program at school because this program is expected to be one of the platforms to suppress aggressive behavior that can occur in adolescents or students in Pekanbaru and its surroundings.
\end{abstract}

Keywords:- Aggressive Behavior, Teenagers, Physical Aggression, Verbal Aggression.

\section{INTRODUCTION}

Adolescence is a period of transition from childhood to adulthood, which includes all aspects such as biological, cognitive, and social (Gunarsa, 2012). Adolescent comes from the Latin language which is adolescere which means grow or to grow maturity to grow to reach maturity (Jahja, 2015). Maturity on all sides, mental, emotional, physical and social maturity. Basically adolescence is a period filled with uncertainty. Where they are no longer classified as children, but also not classified as adults. So that adolescence is also known as the race for identity. Failure to reach maturity will cause various problems in adolescents (Curtis, 2015)

Data from (KPAI, 2016), 33 child brawl victims, 52 brawl children, 97 bullied victims, 112 bullied children, extortion survivors, school dropouts etc. 34 people, 89 children as physical violence perpetrators, children as psychic violence 31 people, children as sexual violence 107 people, children as murderers 36 people, children who are perpetrators of theft 32 people, children who are victims of traffic accidents 51 people, children who have possession of sharp weapons 17 people, children who have abducted 6 people and children as abortion as many as 33 people. In 2019, juvenile delinquency tends to increase. (Rahayu, 2019) said the KPAI commissioner in education explained that violations of children's rights in education were still dominated by physical violence, psychological violence, and sexual violence. Teenagers who are victims of physical violence or aggressive behavior are in second place among other juvenile delinquents.

\section{LITERATUR REVIEW}

Aggressive behavior is a behavior that reflects an overflow of emotions towards the failure of individuals to interact with humans or objects that are intentionally expressed both in words (verbal), and behavior (nonverbal). Teenagers have the tendency to be more aggressive, have unstable emotions, and are easily carried by environmental influences. This is what causes adolescents often experience difficulties when interacting with the environment so it is not uncommon for them to experience difficulties then the response that arises first or is shown is maladaptive responses, one of which is aggressive behavior that can injure themselves and others(Santrock, 2012).

This aggressive behavior can occur directly or indirectly, it can be either passive or aggressive which is displayed in the form of physical or mere words (Rajasakran et al, 2014). This aggressive behavior based on theory consists of four components, namely physical aggressive behavior, verbal, angry feelings, and hostility towards others and the neighborhood (Gallagher et al, 2016).

Based on this description, aggressive behavior has a different form and has a large impact on adolescents so that researchers are interested in seeing how the aggressive behavior of high school students in the city of Pekanbaru. The purpose of this study is to analyze the aggressive behavior that occurs in high school students in Pekanbaru. 


\section{METHOD}

This research uses quantitative research type, with descriptive research design. The study was conducted in 2020, located in the city of Pekanbaru. The population in this study were high school students of Pekanbaru city. The sample in this study amounted to 904 adolescents. The sample technique used is accidental sampling. The research instrument uses the Brief Aggression Questionnaire. This questionnaire is a standard instrument in assessing aggressive behavior in adolescents. Contains 12 statements consisting of four components, namely physical aggression, anger, verbal aggression, and hostility. Each component consists of 3 statements (Webster, 2015).

\section{ANALYSIS}

The results of a study conducted in 2020 with 904 respondents using the Brief Aggression Questionnaire at Pekanbaru High School on Aggressive Behavioral Analysis of High School Students in Pekanbaru City can be seen in the table below:

\begin{tabular}{|c|c|c|c|}
\hline No. & Gender & Frequency & Percentage (\%) \\
\hline 1 & Men & 430 & 47,6 \\
\hline 2 & Woman & 474 & 52,4 \\
\hline \multicolumn{2}{|c|}{ Total } & $\mathbf{9 0 4}$ & $\mathbf{1 0 0}$ \\
\hline
\end{tabular}

Table 1:- Characteristics of Respondents by Gender

Based on the table. 1 above we can see from 904 respondents, the sexes of both men and women do not have differences in numbers that are too significant. Woman gender totaled 474 respondents $(52.4 \%)$, while men totaled 430 respondents $(47.6 \%)$.

\begin{tabular}{|c|c|c|c|}
\hline No. & Age & Frequency & Percentage (\%) \\
\hline 1 & 16 years & 262 & 29 \\
\hline 2 & 17 years & 400 & 44,2 \\
\hline 3 & 18 years & 195 & 21,6 \\
\hline 4 & 19 years & 47 & 5,2 \\
\hline \multicolumn{2}{|c|}{ Total } & $\mathbf{9 0 4}$ & $\mathbf{1 0 0}$ \\
\hline
\end{tabular}

Table 2:- Characteristics of Respondents by Age

Based on the table. 2 above can be seen that of the 904 respondents, the most age is 17 years with a total of 400 respondents $(44.2 \%)$.

\begin{tabular}{|c|c|c|c|}
\hline No. & Variable & Frequency & Percentage (\%) \\
\hline 1 & $\begin{array}{c}\text { Low Aggressive } \\
\text { Behavior }\end{array}$ & 381 & $42,1 \%$ \\
\hline 2 & $\begin{array}{c}\text { High Aggressive } \\
\text { Behavior }\end{array}$ & 523 & $57,9 \%$ \\
\hline \multicolumn{2}{|c|}{ Total } & $\mathbf{9 0 4}$ & $\mathbf{1 0 0}$ \\
\hline
\end{tabular}

Table 3:- Aggressive Behavior in High School Students in Pekanbaru City in 2020

Based on table 3 above we can see that from 904 respondents, $523(57.9 \%)$ respondents showed high aggressive behavior.

\section{DISCUSSION}

Based on research on Aggressive Behavior Analysis in High School Students in Pekanbaru City, the results of 904 respondents $(52.9 \%)$ showed high aggressive behavior, $381(42.1 \%)$ respondents showed low aggressive behavior. Aggressive behavior is a threatening act that is carried out using someone both towards others, objects and the surrounding environment. Aggressive behavior by adolescents basically harms others and the environment. At present there are many actions that indicate aggressive behavior committed by adolescents such as verbal violence, brawls between schools, bullying, and even murder. Based on data from the WHO, 2016 it is estimated that 200,000 aggressive behavior committed by adolescents throughout the world, and this aggressive behavior has become the fourth leading cause of death in adolescents.

Many factors cause the emergence of aggressive behavior in adolescents. Enopadria, 2018 said that selfesteem, aggressive trauma, socioeconomic, interpersonal relationships and social control are some of the factors that trigger the emergence of aggressive behavior in adolescents. Social control is said to be the most dominant factor. Anita, 2019 revealed that there are two triggers for the emergence of aggressive behavior in adolescents, namely internal and external triggers.

Internal triggers consist of pent-up anger and frustration about the burden of life experienced by adolescents. While external triggers come from the provocation of the surrounding environment, the influence of peer groups, peer problems, parents who like to impose wills on their children, communication that is not well established between students, teachers, and parents (Anita, 2019).

Based on the Brief Aggression Questionnaire, there are four components to aggressive behavior, namely physical aggression, anger, verbal aggression, and hostility (Webster, 2015). Physical aggression is the behavior of aggression carried out by means of physical violence, such as slapping, hitting, and throwing other people with objects around them (Setiowati, 2017).

Based on the results of research conducted, signs and symptoms of physical aggression are indicated by 434 (48\%) respondents agree if they have to do violence to protect their rights. And $102(11.3 \%)$ respondents agreed and even strongly agreed that there were people who could influence him to commit violence. The results of this study are in line with research conducted by Hardoni, 2019 which shows the average aggressive behavior of adolescents in $\mathrm{X}$ vocational high schools in Padang City dominated by physical aggression, and anger.

Signs and symptoms of anger that are shown from the results of the study are $294(32.5 \%)$ of respondents said they have a bad temper. $271(30 \%)$ respondents sometimes could not control themselves to be angry even with trivial 
reasons. And 234 (25.9\%) expressed difficulty controlling his anger.

Verbal aggression behavior that is aggression carried out by issuing words to attack others, can be in the form of ridicule, insults, and verbal abuse (Setiowati, 2017). In this study $260(28.8 \%)$ respondents said they would express their opinions loudly if there were any that were not in accordance with the responses or suggestions of others. 385 $(42.6 \%)$ of respondents said they would express their negative thoughts if someone else disturbed them (argumentative). 308 (34.1\%) respondents stated that friends around them said that they liked to argue.

Verbal aggression behavior that is aggression carried out by issuing words to attack others, can be in the form of ridicule, insults, and verbal abuse (Setiowati, 2017). In this study $260(28.8 \%)$ respondents said they would express their opinions loudly if there were any that were not in accordance with the responses or suggestions of others. 385 $(42.6 \%)$ of respondents said they would express their negative thoughts if someone else disturbed them (argumentative). 308 (34.1\%) respondents stated that friends around them said that they liked to argue.

The above description gives us an idea of how aggressive behavior that occurs in high school students in the city of Pekanbaru. Various effects of this aggressive behavior. And also various forms of aggressive behavior ranging from aggressive actions, expressions of anger, words that are not good or hurt the meaning of others, and actions that trigger hostility. If left unchecked this will have an adverse effect on the mental and emotional development of a teenager.

\section{CONCLUSION}

The results of a study conducted in 2020 concerning the analysis of aggressive behavior in high school students in the city of Pekanbaru were from 904 respondents, 523 (57.9\%) respondents showed high aggressive behavior.

\section{REFERENCES}

[1]. Anita. (2019). Bentuk-Bentuk dan Pemicu Perilaku Agresif di Kalangan Siswa SMK Kota Subulussalam. Skripsi Fakultas Tarbiyah Dan Keguruan, Prodi Bimbingan Dan Konseling UIN Ar - Raniry, Banda Aceh.

[2]. Curtis, A. C. (2015). Defining Adolescence. Journal of Adolescent and Family Health, 7(2), 1-39. https://doi.org/http://scholar.utc.edu/jafh/vol7/iss2/2/

[3]. Enopadria, C. (2018). Analisis faktor yang berhubungan dengan perilaku agresif pada remaja di Kota Padang Sumatera Barat tahun 2018. Tesis Magister Keperawatan Universitas Andalas.

[4]. Gallagher, J. M., \& Ashford, J. B. (2016). Buss-Perry Aggression Questionnaire: Testing Alternative Measurement Models With Assaultive Misdemeanor Offenders. Criminal Justice and Behavior, 43(11),
1639-1652. https://doi.org/10.1177/0093854816643 986.

[5]. Gunarsa, Y. S. D. (2012). psikologi Remaja (1st ed.). Jakarta: Libri.

[6]. Hardoni, Yulvi. (2019). Karakteristik Perilaku Agersif Remaja Pada Sekolah Menengah Kejuruan. Jurnal Keperawatan Jiwa, 7(3), 257 - 266.

[7]. Jahja, Y. (2015). Psikologi Perkembangan. Jakarta: Prenadamedia Group.

[8]. KPAI. (2016). Kasus Pengaduan Anak Berdasarkan Klaster Perlindungan Anak, (46), 2016.

[9]. Rahayu, Lisye Sri. (2019). KPAI: Angka Kekerasan pada Anak Januari-April 2019 Masih Tinggi. Retrieved from https://news.detik.com/berita/d4532984/kpai-angka-kekerasan-pada-anak-januariapril-2019-masih-tinggi.

[10]. Rajasakran, T., Wong, A. K. C., S., \& S., Pangiras, G., \& Koran, S. (2014). Aggressor Games: Of Violent Video Games and Aggression among Higherincome Group Schoolchildren in Malaysia. Science Technology \& Society, 19:3, 383-398. Retrieved from https://doi.org/10.1177/0971721814548 113.

[11]. Santrock, J. W. (2012). Life - Span Development, Perkembangan Masa Hidup (Edisi Ketiga Belas) Jilid I. Jakarta: Erlangga.

[12]. Setiowati, E. A. et al. (2017). Gambaran Agresivitas Anak dan Remaja di Area Beresiko. Prosiding Temu Ilmiah Ikatan Psikologi Perkembangan Indonesia., 22 - 24, Agustus 2017, ISBN: 978-602-1145-49-4.

[13]. Webster, Gregory D, et al. (2015). The Brief Aggression Questionnaire: Structure, Validity, Reliability, and Generalizability. Journal of Personality Assessment, $0(0), 1-12$.

[14]. WHO. (2016). Youth Violence. Retrieved from. Retrieved from http://www.who.int/en/news$\% 0$ Aroom/factsheets/detail/youth-\%0Aviolence\%0A. 